DOI: $10.31393 /$ reports-vnmedical-2021-25(2)-08

UDC: $616.314 .26-053.7-073.75$

\title{
CORRELATIONS OF TELERADIOGRAPHIC PARAMETERS OF TEETH LOCATION DETERMINED BY THE METHODS OF BJORK, JARABAK AND SASSOUNI WITH THE PARAMETERS OF THE UPPER AND LOWER JAWS IN YOUNG MEN AND YOUNG WOMEN WITH ORTHOGNATHIC OCCLUSION
}

\section{Vakhovskyi V. V.}

National Pirogov Memorial Medical University, Vinnytsya, (Pyrogov street, 56, Vinnytsya, Ukraine, 21018)

Responsible for correspondence: e-mail: vitalyvahovsky@gmail.com

Received: February, 09, 2021; Accepted: March, 23, 2021

Annotation. Determining the characteristics of certain indicators within a certain population, the relationship between certain anatomical structures and parameters of the human body is one of the key tasks of clinical anthropology. Identifying the nature, strength and direction of the interdependencies of such indicators is a key element not only for understanding human nature but also for solving clinical, including dental problems today. The aim of the study was to establish in Ukrainian young men and young women with orthognathic occlusion the peculiarities of correlations of teleradiographic parameters of tooth location determined by Bjork, Jarabak and Sassouni methods with parameters of upper and lower jaws and tooth location. Teleradiography in the mode of cephalometric examination was performed for 49 young men and 76 young women with orthognathic occlusion. Cephalometric analysis was performed using OnyxCeph ${ }^{3}$ TM software, 3DPro version, Image Instruments GmbH, Germany (software license URSQ-1799). Correlation assessment was performed in the license package "Statistica 6.0" using the non-parametric Spearman method. In young men and young women, the features of multiple correlations of teleradiographic parameters of the upper and lower jaws with the parameters of the location of the teeth determined by the methods of CFT-Bjork, Roth-Jarabak and Sassouni. As a result of quantitative analysis of significant correlations between teleradiographic parameters of the upper and lower jaws with the parameters of the location of the teeth found: CFT-Bjork in young men $46.9 \%$, of which $5.4 \%$ straight strong, $18.5 \%$ straight medium and $2.3 \%$ straight weak and 2.3 $\%$ reversible strong, $16.2 \%$ reversible medium strength and $2.3 \%$ reverse weak, and young women - $38.5 \%$, of which, $2.3 \%$ direct strong, $15.4 \%$ direct medium strength and $6.2 \%$ direct weak and $0.8 \%$ reverse strong, $7.7 \%$ reverse medium strength and $6.2 \%$ of reversible weak; according to the Roth-Jarabak method, $36.2 \%$ of young men, $6.6 \%$ of direct strong, $11.8 \%$ of direct medium strength and $2.6 \%$ of direct weak and $2.6 \%$ of reverse strong, $11.8 \%$ of reverse of medium strength and $0.7 \%$ of reverse weak, and young women - $44.7 \%$, of which, $3.9 \%$ direct strong, $15.1 \%$ direct medium strength and $7.2 \%$ direct weak and $0.7 \%$ reverse strong, $8.6 \%$ reverse medium strength and $9.2 \%$ reverse weak; according to the Sassouni method, $42.8 \%$ of young men have all medium-strength, and $42.8 \%$ of young women have, of which $35.7 \%$ have medium-strength and $7.1 \%$ have weak straight. Manifestations of sexual dimorphism of the received correlations are established only between the indicators defined by CFT-Bjork and Roth-Jarabak methods. Keywords: teleradiography, cephalometry according to the methods of Jarabak, Bjork and Sassouni, correlations, young men and young women with orthognathic occlusion.

\section{Introduction}

Cephalometry occupies one of the key places in the field of biological anthropology and is used in dentistry, forensic medicine, obstetrics and gynecology, pediatrics and more. The clinical approach of cephalometry is cephalometric analysis, the main purpose of which is to assess the relationship between skeletal and dental components of the skull.

After receiving an X-ray image in the lateral projection of the human head set in a special position, the process of applying special landmarks, which later become points, lines, planes and angles. However, further evaluation, interpretation of these landmarks and their derivatives led to the emergence of numerous author's methods of cephalometric analysis.

Data from both domestic and foreign researchers indicate a striking variability of the dental-maxillary system depending on many factors: sex [9], ethnicity [1], facial features $[15,20]$, jaw position [14], regional affiliation [12], features of the structure of the cerebral part of the skull [4], etc.
Thus, Ukrainian researchers in the analysis of teleradiograms of Ukrainian boys and girls by the Steiner method established the relationship of the ANB angle with linear (distance 1u_NA) and angular (angles Max1_NA and Max1_SN) characteristics of the upper central incisors and the angle of the lower central incisors (Mand1_NB) [9].

For residents of Western Ukraine, the largest number of significant correlations between molar size and cranial parameters were found with vestibular-lingual and mesiodistal tooth sizes, and for the facial skull with the height and length of the tooth root [12]. While for the inhabitants of Southern Ukraine the corresponding correlations were found with cranial indicators for tooth height and length of their roots, and for facial skull - with tooth height, root length, vestibular-lingual and mesio-distal dimensions [23].

Thus, there are prerequisites for continuing research in this area in Ukraine. Although Steiner and Downs remain the most common methods of cephalometric analysis, the study of less common methods, such as Jarabak [16, 26, 
27], Bjork [3, 21] and Sassouni [2, 24], is of practical and scientific value.

The aim of the study was to establish in Ukrainian young men and young women with orthognathic occlusion the peculiarities of correlations of teleradiographic parameters of tooth location determined by Bjork, Jarabak and Sassouni methods with parameters of upper and lower jaws and tooth location.

\section{Materials and methods}

49 young men (aged 17 to 21 years) and 76 young women (aged 16 to 20 years) who had an orthognathic occlusion [7] using a dental cone-beam tomograph Veraviewepocs 3D Morita (Japan) underwent teleradiography in the mode of cephalometric examination. Using OnyxCeph ${ }^{3 \mathrm{TM}}$, 3DPro version, Image Instruments $\mathrm{GmbH}$, Germany (software license № URSQ-1799) performed cephalometric studies on modifications of J. R. Jarabak [13] - Roth-Jarabak and A. Bjork [6] - CFT -Bjork, as well as the methods of V. Sassouni [22].

Cephalometric points were determined in accordance with the recommendations of B. S. Phulari [17] and S. I. Doroshenko and E. A. Kulginsky [10].

Indicators determined by the methods of Bjork, Jarabak and Sassouni were divided into three groups [8]. The second group includes metric dental-jaw characteristics in which the bone skeleton is formed and which surgical methods can be used to change the length, width, angles and position of the jaws; to the third group - indicators that characterize the position of each individual tooth relative to each other, cranial structures and the profile of the soft tissues of the face.

The main cephalometric points and measurements according to the CFT-Bjork method:

distance li-ls - the distance from the point Is to li in the vertical plane, characterizes the inter-cut overlap in the vertical plane $(\mathrm{mm})$;

distance li-NCL - the distance from the point $\mathrm{Li}$ to the line Ns-Pog', characterizes the position of the lower lip $(\mathrm{mm})$;

distance Is-NCL - the distance from the point Ls to the line Ns-Pog', characterizes the position of the upper lip $(\mathrm{mm})$;

Is-Olf distance - the distance between the point Is and the closing plane (POcp), characterizes the vertical location of the cutting edge of the medial cutter $(\mathrm{mm})$;

Overjet distance - the distance from the point is to li in the boom plane, characterizes the inter-cutter distance in the sagittal plane $(\mathrm{mm})$;

Wits distance - the distance between the projections of points $A$ and $B$ on the closing plane (POcp), characterizes the linear ratio of the lower and upper jaws along the folding plane $(\mathrm{mm})$;

angle A-N-B - formed by lines A-N and N-B, characterizes the position of the jaws to each other $\left(^{\circ}\right)$;

angle A-N-Pog - formed by lines A-N and N-Pog, characterizes the inter-jaw position in the sagittal plane $\left(^{\circ}\right)$; angle CL/ML - formed by lines Id-Pog and C-Me, characterizes the position of the mandibular cell sprout $\left(^{\circ}\right.$ ); angle ILi/ML - formed by the central axis of the lower medial incisor and the line tGo-Me, characterizes the position of the lower medial incisor to the plane of the mandible $\left({ }^{\circ}\right)$;

the angle ILs/ILi - is formed by the central axes of the upper and lower medial incisors, characterizes the inclination of the upper and lower medial incisors to each other $\left(^{\circ}\right.$ ):

angle ILs/NL - formed by the central axis of the upper medial incisor and the line SpP, characterizes the position of the upper medial incisor to the palatal plane $\left(^{\circ}\right)$;

angle ML/RL - formed by lines Ar-tGo and tGo-Me, characterizes the angle of the lower jaw $\left(^{\circ}\right)$;

angle NL/ML - formed by lines tGo-Me and SpP, characterizes the position of the closing plane to the palatal plane $\left({ }^{\circ}\right)$;

NSL/ML angle - formed by S-N and tGo-Me lines, characterizes the inclination of the mandible to the anterior base of the skull $\left({ }^{\circ}\right)$;

angle NSL/NL - formed by lines S-N and SpP, characterizes the inclination of the upper jaw to the anterior base of the skull $\left({ }^{\circ}\right)$;

angle OLf/NSL - formed by lines S-N and OcP, characterizes the position of the closing plane to the base of the skull $\left(^{\circ}\right)$;

angle $\mathrm{OLi} / \mathbf{M L}$ - formed by lines tGo-Me and OcP, characterizes the position of the closing plane to the mandibular plane $\left(^{\circ}\right)$;

angle OLs/NL - formed by lines SpP and OcP, characterizes the position of the closing plane to the palatal plane $\left({ }^{\circ}\right)$;

angle Pr-N-A - formed by lines A-N and N-Pr, characterizes the position of the maxillary cell sprout $\left({ }^{\circ}\right)$;

angle S-N-A - formed by lines S-N and N-A, characterizes the position of the upper jaw in the sagittal plane $\left(^{\circ}\right)$;

angle S-N-B - formed by lines $\mathrm{S}-\mathrm{N}$ and N-B, characterizes the position of the lower jaw in the sagittal plane $\left(^{\circ}\right)$;

angle S-N-Pog - formed by lines S-N and N-Pog, characterizes the position of the lower jaw in the sagittal plane $\left(^{\circ}\right)$.

Basic cephalometric points and Roth-Jarabak measurements (unlike the original Jarabak analysis, the Roth-Jarabak analysis does not use a specific A-point which is placed $2 \mathrm{~mm}$ in front of the tip of the grayed maxillary incisor, but uses the more common Downs A-point):

distance Go_Me - the distance from the point tGo to the point Me, characterizes the length of the lower jaw $(\mathrm{mm})$;

distance Li-NsPog' - the distance from the point $\mathrm{Li}$ to the line Ns-Pog', characterizes the position of the lower lip relative to the "Aesthetic line" - the line Ns-Pog' (mm).

distance Ls-NsPog' - the distance from the point Ls to the line Ns-Pog', characterizes the position of the upper lip 
relative to the "Aesthetic line" - the line Ns-Pog ( $\mathrm{mm}$ );

$\mathrm{N}$-Go distance - the distance from the point $\mathrm{N}$ to the point tGo, characterizes the height of the bony base of the face, and the actual distance of the chin from the point $\mathrm{N}$ in the vertical plane $(\mathrm{mm})$;

distance $\mathrm{N}-\mathrm{Me}$ - the distance from point $\mathrm{N}$ to point $\mathrm{Me}$, characterizes the anterior height of the face, and the actual distance of the lower point of the chin Me from point $\mathrm{N}$ $(\mathrm{mm})$;

distance S-Gn - the distance from point S to point $\mathrm{Gn}$, characterizes the length of the face determined by the axis $B$, and the actual distance of the chin from the Turkish saddle $(\mathrm{mm})$;

distance S-Go - the distance from the point $S$ to the point $\mathrm{tGo}$, characterizes the posterior height of the face, and the actual distance of the angle of the mandible from the Turkish saddle, also determines the degree of development of the mandibular branch mainly in the vertical plane $(\mathrm{mm})$;

distance 1lo-NPog - the distance from the cutting edge of the lower medial incisor to the line N-Pog, characterizes the anterior-posterior position of the lower medial incisor $(\mathrm{mm})$;

distance 1up-NPog - the distance from the cutting edge of the upper medial incisor to the line N-Pog, characterizes the anterior-posterior position of the upper medial incisor $(\mathrm{mm})$;

angle A-N-B - formed by lines A-N and N-B, characterizes the inter-jaw ratio in the sagittal plane $\left(^{\circ}\right)$;

angle Ar-Go-Gn - formed by lines Ar-tGo and tGo-Gn, characterizes the value of the angle of the lower jaw $\left(^{\circ}\right)$;

angle II - is formed by the central axes of the upper and lower medial incisors, characterizes the angular ratio of the medial incisors of the upper and lower jaws $\left(^{\circ}\right)$;

Mand1-GoMe angle - formed by the central axis of the lower medial incisor and the line tGo-Me, characterizes the inclination of the lower medial incisor to the mandibular plane $\left({ }^{\circ}\right)$;

angle Max1-SN - formed by the central axis of the upper medial incisor and the line S-N, characterizes the inclination of the upper medial incisor to the anterior base of the skull $\left({ }^{\circ}\right)$;

angle N-A-Pog - formed by lines N-A and A-Pog, characterizes the convexity of the bone profile of the face $\left({ }^{\circ}\right)$;

angle N-Go-Ar - formed by lines N-tGo and tGo-Ar, characterizes the angle of inclination of the branch of the mandible to the line $\mathrm{N}-\mathrm{tGo}\left({ }^{\circ}\right)$;

angle N-Go-Gn - formed by lines N-tGo and tGo-Gn, characterizes the angle of the body of the lower jaw to the line $\mathrm{N}$-tGo $\left(^{\circ}\right)$;

angle N-S-Gn - formed by lines N-S and S-tGn, characterizes the direction of the axis of development of the mandible $\left(^{\circ}\right)$;

angle OcP-GoGn - formed by the lines OcP and tGo-Me, characterizes the slope of the closing plane to the mandibular plane $\left(^{\circ}\right)$;

angle S-Ar-Go - formed by the lines S-Ar and Ar-tGo, characterizes the position of the temporomandibular joint and the branch of the mandible $\left({ }^{\circ}\right)$;

angle S-N-A - formed by lines S-N and N-A, characterizes the position of the upper jaw in the sagittal plane $\left(^{\circ}\right)$;

angle S-N-B - formed by lines $\mathrm{S}-\mathrm{N}$ and $\mathrm{N}-\mathrm{B}$, characterizes the position of the lower jaw in the sagittal plane $\left({ }^{\circ}\right)$;

angle SN-GoGn - formed by lines S-N and tGo-Gn, characterizes the inclination of the body of the lower jaw to the anterior base of the skull $\left(^{\circ}\right)$;

angle S-N-Pog - is formed by lines S-N and N-Pog, characterizes the position of the lower jaw, namely the chin in the sagittal plane $\left(^{\circ}\right)$;

Sum - the sum of the angles N-S-Ar, S-Ar-Go and Ar-Go$\mathrm{Gn}$, characterizes the direction of development (vertical when increasing and horizontal when decreasing) of the lower jaw $\left({ }^{\circ}\right)$

the ratio of Go_Me:N-S - the ratio of the distances Go_Me and $\mathrm{N}-\mathrm{S}$, allows you to estimate the degree of development of the lower jaw relative to the anterior base of the skull (\%);

S-Go:N-Me ratio - the ratio of S-Go and N-Me distances, characterizes the ratio between the front and rear face heights (\%).

The main cephalometric points and measurements according to the Sassouni method:

Max-Pos distance - the distance from the ANS point to the anterior arch (Anterior Arc), characterizes the position of the upper jaw in the sagittal plane $(\mathrm{mm})$;

Mand-Pos distance - the distance from the Pog point to the anterior arch (Anterior Arc), characterizes the position of the lower jaw (bone chin) in the sagittal plane $(\mathrm{mm})$;

Max-Mand distance - the distance from the Pog point to the spinal arch (ANS Arc), characterizes the position of the lower jaw relative to the upper $(\mathrm{mm})$;

Max-Bas distance - the distance from point $B$ to the basal arch (Basal Arc), characterizes the position of the base of the lower jaw relative to the base of the upper $(\mathrm{mm})$;

Pos-Gon distance - the distance from the Go point to the posterior arch (Posterior Arc), characterizes the position of the angle of the lower jaw in the sagittal plane $(\mathrm{mm})$;

Pos-Inc distance - the distance from the point Is $1 \mathrm{u}$ to the anterior spinal arch (ANS Arc), characterizes the position of the central medial incisor of the upper jaw relative to the base of the upper in the sagittal plane $(\mathrm{mm})$;

Pos-Mol distance - the distance from point A6u to the midfacial arch (Midfacial Arc), characterizes the position of the first molar relative to the midfacial arch in the sagittal plane $(\mathrm{mm})$;

Ant-Fac-Heig distance - the distance from the point Me to the circle with the radius ANS-RO increased by $10 \mathrm{~mm}$ drawn from the point ANS, characterizes the position of the chin in the vertical plane $(\mathrm{mm})$;

Post-Fac-Heig distance - the distance from the point 
Go to the circle of radius PNS-Si drawn from the point PNS, characterizes the position of the angle of the mandible in the vertical plane $(\mathrm{mm})$.

Committee on Bioethics of National Pirogov Memorial Medical University, Vinnytsya (Minutes № 8 of 18.10.2019) found that the studies meet the bioethical and moral requirements of the Declaration of Helsinki, the Council of Europe Convention on Human Rights and Biomedicine (1977), the relevant provisions of the WHO and the laws of Ukraine.

Correlation was assessed using the non-parametric
Spearman method in the "Statistica 6.0" license package.

\section{Results. Discussion}

The results of the evaluation of the correlations between the indicators of the second group according to the methods of CFT-Bjork, Roth-Jarabak or Sassouni with the indicators of the third group are presented in tables 1-3.

Analysis of teleradiographic parameters by the Sassouni method in the Moroccan sample revealed correlations between the upper alveolar height and the anterior, posterior height of the face; lower alveolar height

Table 1. Correlations of the second group of indicators according to the CFT-Bjork method (names of indicators without color selection) with the third group (names of indicators are highlighted in light gray).

\begin{tabular}{|c|c|c|c|c|c|c|c|c|c|c|}
\hline \multirow{2}{*}{ Indexes } & \multicolumn{10}{|c|}{ Young men } \\
\hline & S-N-A & S-N-Pog & S-N-B & A-N-Pog & A-N-B & NSL/NL & NSL/ML & NL/ML & li-ls & ML/RL \\
\hline Pr-N-A & 0,06 & 0,24 & 0,25 & $-0,27$ & $-0,34$ & $-0,32$ & $-0,16$ & 0,04 & $-0,08$ & $-0,08$ \\
\hline $\mathrm{CL} / \mathrm{ML}$ & 0,42 & 0,03 & 0,17 & 0,58 & 0,50 & $-0,24$ & $-0,32$ & $-0,22$ & 0,14 & $-0,28$ \\
\hline ILs/NL & 0,55 & 0,64 & 0,68 & $-0,27$ & $-0,32$ & $-0,19$ & $-0,44$ & $-0,46$ & $-0,19$ & $-0,13$ \\
\hline ILi/ML & 0,52 & 0,21 & 0,26 & 0,42 & 0,50 & $-0,32$ & $-0,52$ & $-0,44$ & 0,15 & $-0,53$ \\
\hline ILs/ILi & $-0,54$ & $-0,27$ & $-0,38$ & $-0,31$ & $-0,29$ & 0,41 & 0,29 & 0,12 & 0,15 & 0,11 \\
\hline Overjet & 0,45 & 0,22 & 0,29 & 0,35 & 0,41 & $-0,45$ & $-0,44$ & $-0,27$ & 0,40 & $-0,35$ \\
\hline Wits & 0,22 & $-0,10$ & $-0,13$ & 0,49 & 0,66 & 0,00 & $-0,16$ & $-0,21$ & 0,25 & $-0,26$ \\
\hline OLs/NL & $-0,46$ & $-0,59$ & $-0,55$ & 0,29 & 0,23 & $-0,02$ & 0,45 & 0,61 & 0,19 & 0,08 \\
\hline OLi/ML & $-0,28$ & $-0,27$ & $-0,29$ & 0,03 & 0,05 & 0,21 & 0,56 & 0,57 & 0,03 & 0,50 \\
\hline OLf/NSL & $-0,62$ & $-0,82$ & $-0,78$ & 0,41 & 0,33 & 0,52 & 0,82 & 0,73 & $-0,13$ & 0,36 \\
\hline Is-OLf & 0,00 & $-0,06$ & $-0,07$ & 0,11 & 0,18 & 0,15 & $-0,17$ & $-0,33$ & 0,62 & $-0,32$ \\
\hline Is-NCL & 0,07 & $-0,21$ & $-0,09$ & 0,47 & 0,39 & 0,12 & 0,05 & $-0,01$ & $-0,04$ & 0,12 \\
\hline \multirow[t]{2}{*}{ Ii-NCL } & 0,09 & $-0,21$ & $-0,08$ & 0,50 & 0,39 & 0,11 & 0,18 & 0,19 & $-0,02$ & 0,24 \\
\hline & \multicolumn{10}{|c|}{ Young women } \\
\hline Pr-N-A & $-0,34$ & $-0,10$ & $-0,04$ & $-0,36$ & $-0,53$ & $-0,24$ & 0,14 & 0,33 & $-0,07$ & 0,04 \\
\hline CL/ML & 0,10 & $-0,32$ & $-0,15$ & 0,55 & 0,38 & 0,02 & $-0,08$ & $-0,13$ & $-0,09$ & $-0,28$ \\
\hline ILs/NL & 0,14 & 0,18 & 0,27 & $-0,03$ & $-0,17$ & 0,26 & $-0,07$ & $-0,22$ & $-0,10$ & 0,02 \\
\hline ILi/ML & 0,16 & $-0,20$ & $-0,14$ & 0,51 & 0,50 & 0,03 & $-0,25$ & $-0,34$ & $-0,11$ & $-0,41$ \\
\hline ILs/lLi & $-0,09$ & 0,20 & 0,07 & $-0,38$ & $-0,24$ & $-0,08$ & $-0,13$ & $-0,09$ & 0,16 & $-0,03$ \\
\hline Overjet & 0,19 & $-0,10$ & $-0,08$ & 0,39 & 0,43 & 0,03 & $-0,04$ & $-0,05$ & 0,36 & $-0,04$ \\
\hline Wits & 0,27 & $-0,13$ & $-0,14$ & 0,59 & 0,74 & 0,20 & $-0,08$ & $-0,26$ & 0,13 & $-0,04$ \\
\hline OLs/NL & $-0,24$ & $-0,28$ & $-0,26$ & $-0,03$ & $-0,07$ & $-0,39$ & 0,29 & 0,59 & 0,13 & 0,10 \\
\hline OLi/ML & $-0,05$ & $-0,10$ & $-0,06$ & 0,05 & $-0,01$ & 0,12 & 0,54 & 0,55 & 0,13 & 0,70 \\
\hline OLf/NSL & $-0,45$ & $-0,65$ & $-0,58$ & 0,19 & 0,06 & 0,38 & 0,67 & 0,45 & $-0,12$ & 0,20 \\
\hline Is-OLf & 0,12 & $-0,09$ & $-0,10$ & 0,25 & 0,33 & 0,07 & $-0,03$ & $-0,11$ & 0,46 & 0,03 \\
\hline Is-NCL & 0,27 & $-0,10$ & 0,05 & 0,52 & 0,43 & 0,02 & 0,09 & 0,08 & 0,00 & 0,05 \\
\hline li-NCL & 0,16 & $-0,22$ & $-0,06$ & 0,50 & 0,35 & $-0,01$ & 0,25 & 0,29 & $-0,07$ & 0,22 \\
\hline
\end{tabular}

Notes: here and in the following tables, reliable direct strong correlations are highlighted in red; reliable straight average correlation force are highlighted in magenta; significant direct weak correlations are highlighted in yellow; significant inverse strong correlations are highlighted in purple; the significant inverse mean correlations are highlighted in blue; significant inverse weak correlations are highlighted in green. 
Table 2. Correlations of the second group of indicators according to the Roth-Jarabak method (names of indicators are highlighted in light gray) with the third group (names of indicators without color highlighting).

\begin{tabular}{|c|c|c|c|c|c|c|c|c|}
\hline \multirow{2}{*}{ Indexes } & \multicolumn{8}{|c|}{ Young men } \\
\hline & OcP-GoGn & II & Max1-SN & Mand1-GoMe & 1up-NPog & 1lo-NPog & Ls-NsPog' & Li-NsPog' \\
\hline S-Ar-Go & 0,03 & 0,25 & $-0,16$ & $-0,11$ & $-0,25$ & $-0,11$ & $-0,21$ & $-0,09$ \\
\hline Ar-Go-Gn & 0,57 & 0,12 & $-0,18$ & $-0,53$ & 0,17 & 0,17 & 0,11 & 0,23 \\
\hline Sum & 0,63 & 0,29 & $-0,61$ & $-0,53$ & 0,16 & 0,23 & 0,03 & 0,14 \\
\hline N-Go-Ar & 0,10 & $-0,16$ & 0,31 & $-0,04$ & 0,05 & $-0,09$ & 0,21 & 0,08 \\
\hline N-Go-Gn & 0,68 & 0,23 & $-0,44$ & $-0,59$ & 0,18 & 0,26 & 0,01 & 0,18 \\
\hline Go_Me & $-0,18$ & $-0,08$ & 0,28 & 0,19 & $-0,16$ & $-0,18$ & $-0,23$ & $-0,26$ \\
\hline Go_Me:N-S & $-0,02$ & $-0,07$ & 0,17 & 0,08 & $-0,06$ & $-0,02$ & $-0,28$ & $-0,23$ \\
\hline S-N-A & $-0,29$ & $-0,52$ & 0,60 & 0,50 & 0,33 & 0,28 & 0,05 & 0,12 \\
\hline S-N-B & $-0,31$ & $-0,36$ & 0,78 & 0,25 & 0,00 & $-0,07$ & $-0,13$ & $-0,05$ \\
\hline$A-N-B$ & 0,02 & $-0,32$ & $-0,31$ & 0,48 & 0,68 & 0,71 & 0,36 & 0,36 \\
\hline SN-GoGn & 0,63 & 0,29 & $-0,61$ & $-0,53$ & 0,16 & 0,23 & 0,03 & 0,14 \\
\hline N-Go & $-0,32$ & $-0,04$ & 0,00 & 0,38 & $-0,13$ & $-0,14$ & $-0,10$ & $-0,20$ \\
\hline S-Gn & 0,22 & $-0,08$ & 0,31 & $-0,14$ & $-0,05$ & $-0,06$ & $-0,31$ & $-0,13$ \\
\hline N-S-Gn & 0,41 & 0,26 & $-0,71$ & $-0,31$ & 0,19 & 0,29 & 0,07 & 0,14 \\
\hline S-Go & $-0,42$ & $-0,26$ & 0,44 & 0,43 & $-0,05$ & $-0,07$ & $-0,13$ & $-0,17$ \\
\hline N-Me & 0,37 & 0,09 & $-0,32$ & $-0,24$ & 0,13 & 0,19 & $-0,11$ & 0,01 \\
\hline S-Go:N-Me & $-0,62$ & $-0,30$ & 0,59 & 0,52 & $-0,12$ & $-0,19$ & $-0,02$ & $-0,11$ \\
\hline S-N-Pog & $-0,26$ & $-0,25$ & 0,76 & 0,19 & $-0,19$ & $-0,26$ & $-0,22$ & $-0,17$ \\
\hline \multirow[t]{2}{*}{ N-A-Pog } & $-0,01$ & $-0,34$ & $-0,32$ & 0,43 & 0,77 & 0,80 & 0,47 & 0,50 \\
\hline & \multicolumn{8}{|c|}{ Young women } \\
\hline S-Ar-Go & $-0,27$ & $-0,07$ & $-0,06$ & 0,25 & 0,07 & 0,06 & 0,14 & 0,03 \\
\hline Ar-Go-Gn & 0,72 & $-0,04$ & $-0,09$ & $-0,41$ & 0,17 & 0,21 & 0,03 & 0,22 \\
\hline Sum & 0,61 & $-0,12$ & $-0,38$ & $-0,25$ & 0,32 & 0,39 & 0,07 & 0,25 \\
\hline N-Go-Ar & 0,39 & 0,05 & 0,13 & $-0,29$ & $-0,04$ & $-0,05$ & 0,00 & 0,09 \\
\hline N-Go-Gn & 0,73 & $-0,06$ & $-0,28$ & $-0,37$ & 0,26 & 0,33 & 0,02 & 0,23 \\
\hline Go_Me & $-0,31$ & $-0,03$ & 0,34 & 0,03 & $-0,21$ & $-0,28$ & $-0,15$ & $-0,18$ \\
\hline Go_Me:N-S & $-0,19$ & $-0,01$ & 0,31 & $-0,11$ & $-0,13$ & $-0,17$ & $-0,06$ & $-0,09$ \\
\hline S-N-A & $-0,09$ & $-0,08$ & 0,26 & 0,15 & 0,24 & 0,18 & 0,28 & 0,18 \\
\hline S-N-B & $-0,09$ & 0,08 & 0,53 & $-0,15$ & $-0,13$ & $-0,19$ & 0,05 & $-0,07$ \\
\hline A-N-B & $-0,01$ & $-0,24$ & $-0,31$ & 0,48 & 0,57 & 0,56 & 0,40 & 0,34 \\
\hline SN-GoGn & 0,61 & $-0,12$ & $-0,38$ & $-0,25$ & 0,32 & 0,39 & 0,07 & 0,25 \\
\hline N-Go & $-0,44$ & 0,00 & $-0,03$ & 0,34 & $-0,14$ & $-0,16$ & $-0,24$ & $-0,27$ \\
\hline S-Gn & 0,21 & 0,04 & 0,08 & $-0,20$ & $-0,14$ & $-0,15$ & $-0,24$ & $-0,18$ \\
\hline N-S-Gn & 0,29 & $-0,16$ & $-0,44$ & 0,03 & 0,34 & 0,39 & 0,03 & 0,18 \\
\hline S-Go & $-0,46$ & 0,04 & 0,13 & 0,30 & $-0,18$ & $-0,21$ & $-0,19$ & $-0,27$ \\
\hline N-Me & 0,27 & $-0,06$ & $-0,26$ & $-0,03$ & 0,07 & 0,10 & $-0,19$ & $-0,05$ \\
\hline S-Go:N-Me & $-0,60$ & 0,12 & 0,31 & 0,28 & $-0,27$ & $-0,33$ & $-0,07$ & $-0,25$ \\
\hline S-N-Pog & $-0,15$ & 0,18 & 0,49 & $-0,19$ & $-0,32$ & $-0,37$ & $-0,09$ & $-0,21$ \\
\hline N-A-Pog & 0,03 & $-0,38$ & $-0,22$ & 0,51 & 0,76 & 0,76 & 0,51 & 0,48 \\
\hline
\end{tabular}


Table 3. Correlations of the second group of indicators according to the Sassouni method (names of indicators are highlighted in light gray) with the third group (names of indicators without color highlighting).

\begin{tabular}{|l|c|c|c|c|}
\hline \multirow{2}{*}{ Indexes } & \multicolumn{2}{|c|}{ Young men } & \multicolumn{2}{c|}{ Young women } \\
\cline { 2 - 5 } & Pos-Inc & Pos-Mol & Pos-Inc & Pos-Mol \\
\hline Max-Pos & $-0,21$ & $\mathbf{0 , 4 8}$ & $-0,08$ & $\mathbf{0 , 5 2}$ \\
\hline Mand-Pos & $\mathbf{0 , 3 8}$ & $\mathbf{0 , 4 4}$ & $\mathbf{0 , 2 3}$ & $\mathbf{0 , 4 3}$ \\
\hline Max-Mand & $\mathbf{0 , 5 5}$ & 0,03 & $\mathbf{0 , 4 1}$ & 0,02 \\
\hline Max-Bas & $\mathbf{0 , 4 3}$ & 0,03 & $\mathbf{0 , 4 1}$ & 0,03 \\
\hline Pos-Gon & 0,15 & $\mathbf{0 , 4 5}$ & 0,15 & $\mathbf{0 , 3 6}$ \\
\hline Ant-Fac-Heig & 0,05 & $-0,28$ & 0,00 & $-0,16$ \\
\hline Post-Fac-Heig & 0,12 & 0,16 & $-0,23$ & $-0,08$ \\
\hline
\end{tabular}

and posterior height of the face; lower anterior alveolar height and facial height index [1].

When comparing the effectiveness of Sassouni and Delaire cephalometric analysis methods, it was found that the Sassouni method was more effective due to greater balance $(16.4 / 14=+2.6)$. The Sassouni method is effective for both vertical and horizontal modifications of the upper jaw [5].

In addition, the use of orthodontic treatment by Sassouni can improve the inter incision ratio at the tooth-alveolar level and allows you to move forward the lower jaw [11].

S. Krasteva and others assessed the severity of facial asymmetry using cephalometric analysis of indicators according to the method of Sassouni. The analysis of the sample showed that $51.5 \%$ of the subjects had asymmetry of the upper and lower jaw, while $48.5 \%$ only asymmetry of the lower jaw [14].

Cephalometric research methods can be used to study ancient migration processes. A group of authors studied 149 skulls from the Bahari oasis of the Greco-Romanesque period. The researchers used cephalometric analysis according to Sassouni. It was found that the representatives who lived in this region have sharp differences with other morphotypes found in modern Egypt [29].

Roth-Jarabak analysis of cephalometric parameters revealed correlations between airway volume and saddle angle, sella nasion point $A$ and $B(p<0.05)$ [2].

M. Pokharel and S. L. Shrestha [18] were the first to study the features of Jarabak indicators for members of the Brahmin caste in Nepal. In addition to identifying differences in the study and control samples, the authors also found manifestations of sexual dimorphism.

A group of researchers analyzed 144 teleradiograms for Jarabak. The statistical analysis of the obtained data revealed that the larger size of the frontal sinus had a negative correlation with the inclination of the anterior cranial base and a positive correlation with an increase in the anterior height of the face [25].

S. S. Agarwal and B. C. C. Base [4] proved by analyzing teleradiographic parameters by the Bjork method that the angle of the skull base does not affect the vertical parameters of the face. If we take into account the type of human face, the angle of the skull base correlates with the posterior base of the skull in hypodivergent face type.

Fifteen pairs of twins underwent a cephalometric study using Bjork and DNA typing. The authors of the study found that there are hereditary components that are responsible for the length of the lower jaw, the angle of the saddle, the anterior cranial base, anterior and posterior height of the face and the gonial angle. At the same time, no hereditary elements have been identified for such indicators as upper and lower anterior facial height [19].

The influence of Bjork cephalometric components on the facial profile was revealed. Only the joint angle was significantly larger with a convex face type. For other skeletal parameters, no statistically significant effect on the facial profile was found [20].

In the analysis of multiple reliable correlations of teleradiographic parameters of the upper and lower jaws (second group) with the parameters of the location of the teeth (third group) according to the CFT-Bjork method in Ukrainian young men and young women with orthognathic occlusion:

in young men - mostly straight of medium strength $(r=$ from 0.29 to 0.66 ), the correlations between the magnitude of the angles A-N-Pog and A-N-B from 2/3 of the third group; direct strong and medium strength ( $r=$ from 0.45 to 0.82 ) correlations of the magnitude of the angles NSL/ML and $\mathrm{NL} / \mathrm{ML}$ with the magnitude of the angles $\mathrm{OLs} / \mathrm{NL}$, OLi/ML and OLf/NSL and medium strength inverse $(r=$ from -0.44 to -0.52$)$ correlations with the magnitude of the angles ILs/ $\mathrm{NL}$ and ILi/ML; medium-strength ( $r=$ from 0.42 to 0.55$)$ the correlations of the value of the angle S-N-A with the value of the angles CL/ML, OLs/NL, OLi/ML and the distance Overjet and, preferably of medium strength, the inverse ( $r=$ from 0.28 to -0.62 ) correlations with the magnitude of the angles ILs/ILi, OLs/NL, OLi/ML and OLf/NSL; predominantly inverse of medium strength $(r=-0.29$ to -0.78$)$, the correlations of the value of the angle S-N-B with the value of the angles ILs/ILi, OLs/NL, OLi/ML and OLf/NSL;

in young women - mostly straight lines of medium strength ( $r=$ from 0.25 to 0.74 ), the correlations between the magnitude of the angles A-N-Pog and A-N-B more than half of the third group; mostly straight lines of medium strength ( $r=$ from 0.29 to 0.67 ), the correlations of the magnitude of the angles NSL/ML and NL/ML with almost half of the third group.

A quantitative analysis of significant correlations between the indicators of the second group with the indicators of the third group according to the CFT-Bjork method in Ukrainian young men and young women with orthognathic occlusion revealed the following distribution of correlations:

in young men - 61 correlations out of 130 possible (46.9 $\%$ ), of which, $5.4 \%$ direct strong, $18.5 \%$ direct medium strength and $2.3 \%$ direct weak and $2.3 \%$ reverse strong, 
$16.2 \%$ reverse medium strength and $2.3 \%$ reverse weak; young women have 50 correlations out of 130 possible (38.5\%), of which $2.3 \%$ are direct strong, $15.4 \%$ are direct medium strength and $6.2 \%$ are direct weak and $0.8 \%$ are reverse strong, $7.7 \%$ are reverse medium strength and $6.2 \%$ are reverse weak.

It should be noted that in previous studies in the analysis of the correlations between the characteristics of basal cranial structures (first group) with teleradiographic parameters of the upper and lower jaws (second group) and the location of teeth (third group) by CFT-Bjork in young men on average $18.1 \%$ direct average correlations, and young women - an average of $28.9 \%$ evenly direct and inverse average correlations [28].

In the analysis of multiple reliable correlations of teleradiographic parameters of the upper and lower jaws (second group) with the parameters of the location of the teeth (third group) according to the Roth-Jarabak method in Ukrainian young men and young women with orthognathic occlusion:

in young men - direct strong and medium strength $(r=$ from 0.37 to 0.68 ) correlations of the value of the angle OcP-GoGn with the value of the angles Ar-Go-Gn, N-GoGn, SN-GoGn and NS-Gn, the distance N-Me and Sum, as well as inverse, mostly medium strength ( $r=$ from -0.29 to -0.62 ), correlations with the value of the angles S-N-A, S-N$\mathrm{B}$, distances $\mathrm{N}-\mathrm{Go}_{0}$ and $\mathrm{S}-\mathrm{Go}_{0}$ and the ratio $\mathrm{S}-\mathrm{Go}_{\mathrm{N}} \mathrm{N}-\mathrm{Me}$; inverse mean forces $(r=-0.30$ to -0.52$)$ correlations of the value of the angle II with the value of the angles $\mathrm{S}-\mathrm{N}-\mathrm{A}, \mathrm{S}-\mathrm{N}$ B, A-N-B, SN-GoGn and N-A-Pog and the ratio S-Go:N-Me; direct strong and medium strength ( $r=$ from 0.31 to 0.78 ) correlations of the value of the angle Max1-SN with the value of the angles N-Go-Ar, S-N-A, S-N-B and SN-Pog, the distance $\mathrm{S}-\mathrm{Gn}$ and the ratio $\mathrm{S}-\mathrm{Go}: \mathrm{N}-\mathrm{Me}$; medium-strength direct ( $r=$ from 0.38 to 0.52 ) correlations of the value of the angle Mand1-GoMe with the value of the angles S-N-A, A$\mathrm{N}-\mathrm{B}$ and N-A-Pog, the distances N-Go and S-Go and the ratio S-Go:N-Me, and medium-strength inverse ( $r=$ from 0.31 to -0.59 ) correlations with the magnitude of the angles Ar-Go-Gn, N-Go-Gn, SN-GoGn and NS-Gn and Sum; direct strong and medium strength ( $r=$ from 0.36 to 0.80 ) correlations of the magnitude of the angles $\mathrm{A}-\mathrm{N}-\mathrm{B}$ and N-APog with the distances 1 up-NPog, 1lo-NPog, Ls-NsPog' and Li-NsPog' attract attention;

in young women - direct, mostly strong $(r=$ from 0.27 to 0.72), the correlations of the magnitude of the angle OcPGoGn with the magnitude of the angles Ar-Go-Gn, N-Go-Ar, N-Go-Gn, SN-GoGn and N-S-Gn, distances N-Me and Sum, as well as inverse, mostly medium strength ( $r=$ from -0.29 to -0.62 ), correlations with the value of the angle S-Ar-Go, distances Go_Me, N-Go and S- Go and the S-Go:N-Me ratio; direct, mainly medium-strength ( $r=$ from 0.26 to 0.49 ) correlations of the value of the angle Max1-SN with the value of the angles S-N-A, S-N-B and S-N-Pog, the distance Go_Me and the ratios Go_Me:N-S and S-Go:N-Me; straight lines, mainly of medium strength ( $r=$ from 0.25 to 0.51 ), the correlations of the magnitude of the angle Mand1-GoMe with the magnitude of the angles S-Ar-Go, ANB and N-APog, the distances $\mathrm{N}-\mathrm{Go}_{0}$ and $\mathrm{S}-\mathrm{Go}_{0}$ and the ratio $\mathrm{S}-\mathrm{Go}_{\mathrm{N}} \mathrm{N}$ $\mathrm{Me}$, as well as inverse, mostly weak ( $r=$ from -0.25 to 0.41 ), correlations with the magnitude of the angles Ar-GoGn, N-Go-Ar, N-Go-Gn and SN-GoGn and Sum indicator; straight, mainly of medium strength ( $r=$ from 0.26 to 0.76 ), correlations of distances 1 up-NPog and 1lo-NPog with the value of the angles N-Go-Gn, ANB, SN-GoGn, NS-Gn and NA-Pog and Sum, as well as inverse, mostly medium strength ( $r=$ from -0.27 to 0.37 ), correlations with the value of the angle SN-Pog and the ratio S-Go:N-Me; straight, mostly weak ( $r=0.23$ to 0.48 ), Li-NsPog' distance correlations with N-Go-Gn, A-N-B, SN-GoGn and N-A-Pog angles and Sum.

A quantitative analysis of significant correlations between the indicators of the second group with the indicators of the third group according to the Roth-Jarabak method in Ukrainian young men and young women with orthognathic occlusion revealed the following distribution of correlations:

in young men - 55 correlations out of 152 possible (36.2 $\%$ ), of which, $6.6 \%$ direct strong, $11.8 \%$ direct medium strength and $2.6 \%$ direct weak and $2.6 \%$ reverse strong, $11.8 \%$ reverse medium strength and $0.7 \%$ reverse weak;

in young women - 68 correlations out of 152 possible (44.7\%), of which, $3.9 \%$ direct strong, $15.1 \%$ direct medium strength and $7.2 \%$ direct weak and $0.7 \%$ reverse strong, $8.6 \%$ reverse medium strength and $9.2 \%$ reverse weak.

In previous studies, the analysis of the correlations between the characteristics of basal cranial structures (first group) with teleradiographic parameters of the upper and lower jaws (second group) and the location of teeth (third group) by the Roth-Jarabak method in young men found an average of $35.5 \%$ feedback, and in young women - on average $26.8 \%$ are also mostly of medium strength direct and feedback [28].

In the analysis of multiple reliable correlations of teleradiographic parameters of the upper and lower jaws (second group) with the parameters of the location of the teeth (third group) according to the Sassouni method in Ukrainian young men and young women with orthognathic occlusion in both young men and young women established in almost all cases of moderate strength $(r=$ from 0.23 to 0.55 ), Pos-Inc distance correlations with MandPos, Max-Mand and Max-Bas distances, Pos-Mol distances - with Max-Pos, Mand-Pos and Pos-Gon distances.

A quantitative analysis of significant correlations between the indicators of the second group with the indicators of the third group according to the Sassouni method in Ukrainian young men and young women with orthognathic occlusion revealed the following distribution of correlations:

in young men - 6 correlations out of 14 possible (42.8 $\%$ ), all straight of medium strength; 
in young women - 6 correlations out of 14 possible $(42.8 \%)$, of which, $35.7 \%$ of direct medium strength and $7.1 \%$ of direct weak.

\section{Conclusions and prospects for further development}

1. Qualitative and quantitative features of correlations of teleradiographic parameters of the upper and lower jaws with the parameters of tooth location determined by the methods of CFT-Bjork, Roth-Jarabak and Sassouni have been established in Ukrainian young men and young women with orthognathic occlusion.

2. Manifestations of sexual dimorphism of correlations of teleradiographic parameters of the upper and lower jaws

\section{References}

[1] Abdelali, H., Benyahia, H., Abouqal, R., Azaroual, M. F., \& Zaoui, F. (2012). Associations between alveolar heights and vertical skeletal pattern in Moroccan adults: a cephalometric study of 127 clinical cases. International orthodontics, 10(1), 43-53. https://doi.org/10.1016/j.ortho.2011.09.001

[2] Abdelkarim, A. (2012). A cone beam CT evaluation of oropharyngeal airway space and its relationship to mandibular position and dentocraniofacial morphology. Journal of the World Federation of Orthodontists, 1(2), e55-e59. https://doi.org/ 10.1016/j.ejwf.2012.06.001

[3] Agarwal, A., Pandey, H., Bajaj, K., \& Pandey, L. (2013). Changes in cranial base morphology in class I and class II division 1 malocclusions. Journal of international oral health: JIOH, 5(1), 39-42. PMID: 24155576

[4] Agarwal, S. S., \& Base, B. C. C. Correlating Cranial Base Flexure And Posterior Cranial Base Length With Vertical Skeletal Patterns. IJDRR, 2, 13.

[5] Bardet, I., Goudot, P., Kerbrat, J. B., \& Mauchamp, O. (2019). Surgery First: prediction for skeletal objectives through structural analysis. Comparison of Sassouni and Delaire analysis. L'Orthodontie francaise, 90(1), 37-54. https://doi.org/ 10.1051/orthodfr/2019004

[6] Björk, A. (1966). Sutural growth of the upper face studied by the implant method. Acta Odontologica Scandinavica, 24(2), 109-127. doi: 10.3109/00016356609026122

[7] Bushan, M. H., Vasylenko, Z. S., \& Hryhoreva, L. P. (1990). Справочник по ортодонти [Handbook of orthodontics]. Ки шенев: Картя Молдовеняскэ - Kishinev: Kartia Moldoveniaske.

[8] Dmitriev, М. О. (2017). Зв'язки основних краніальних показників з характеристиками положення зубів верхньої і нижньої щелеп та профілем м'яких тканин обличчя в юнаків дівчат [Relations of key cranial indicators with the characteristics of the teeth of the upper and lower jaws and profile face soft tissue in boys and girls]. Вісник морфоологіi - Reports of Morphology, 23(1), 125-131.

[9] Dmitriev, M., Gunas, V., Polishchuk, S., Olkhova, I., \& Kumar, A. (2020). Modeling of Central Incisors Position Indicators in boys and girls according to CC. Steiner method for Forensic Dental Identification. The Official Publication of Indian Academy of Forensic Medicine, 42(3), 155-160. https://doi.org/10.5958/ 0974-0848.2020.00043.3

[10] Doroshenko, S. I., \& Kulginsky, Е. А. (2007). Основы телерентгенографрии [Fundamentals of teleradiography]. К.: Здоров'я - K.: Zdorovija.

[11] Flis, P. S., Filonenko, V. V., \& Doroshenko, N. M. (2017). Cephalometric Sassouni plus analysis usage for evaluating the effectivenss of distal bite treatment with an orthodontic with the parameters of tooth location determined by CFTBjork, Roth-Jarabak and Sassouni methods are established only for CFT-Bjork and Roth-Jarabak methods.

The established features of correlations of teleradiographic parameters of the upper and lower jaws with the parameters of tooth location determined in Ukrainian young men and young women with orthognathic occlusion by CFT-Bjork, Roth-Jarabak and Sassouni methods expand the scientists' understanding of correct analysis of lateral teleradiograms according to these methods and will allow in the future dentists to take a more reasonable approach to the interpretation of the results obtained in patients.

appliance with a movale ramp. Ukrainian Dental Almanac, 2, 43-48.

[12] Gunas, V. I., Kotsyura, O. O., Babych, L. V., Shevchuk, Y. G., \& Cherkasova, O. V. (2020). Features correlations of the sizes of molars with cephalometric indicators of men of the western region of Ukraine. Reports of Morphology, 26(2), 51-61. https:/ /doi.org/10.31393/morphology-journal-2020-26(2)-08

[13] Jarabak, J. R., \& Fizzell, J. A. (1972). Technique and treatment with light-wire edgewise appliances, ed. 2, St. Louis, The CV Mosby Company. ISBN 9780801624292

[14] Krasteva, S., Boeva, T., \& Yovcheva, K. (2020). Cephalometric graphical evaluation of the exact location of transverse maxillofacial discrepancies. Knowledge International Journal, 43(4), 649-655.

[15] Marchenko, A. V., Shinkaruk-Dykovytska, M. M., Pozur, T. P., Gunas, V. I., \& Orlovskiy, V. O. (2020). Models of individual linear dimensions necessary for the construction of the correct form of dental arches in young men with a wide face, depending on the features of odontometric and cephalometric indicators. Wiadomosci lekarskie (Warsaw, Poland: 1960), 73(6), 11031107. PMID: 32723934

[16] Murali, R. V., Sukumar, M. R., Tajir, T. F., \& Rajalingam, S. (2011). Comparative study of manual cephalometric tracing and computerized cephalometric tracing in digital lateral cephalogram for accuracy and reliability of landmarks. Indian Journal of Multidisciplinary Dentistry, 1(3), 126-133.

[17] Phulari, B. (2013). An atlas on cephalometric landmarks. JP Medical Ltd. doi: 10.5005/jp/books/11877

[18] Pokharel, M., \& Shrestha, S. L. (2019). Cephalometric evaluation of Brahmins of Kathmandu, Nepal based on Jarabak's analysis. Journal of Kathmandu Medical College, 8(1), 13-19. https:// doi.org/10.3126/jkmc.v8i1.2526

[19] Reddy, Y. M., Sreekanth, C. A. B., Reddy, B. V., \& Kumar, B. L. (2011). The effect of genetic and environmental factors on craniofacial complex: A twin study. Journal of Indian Orthodontic Society, 45(3), 105-109. https://doi.org/10.5005/ jp-journals-10021-1019

[20] Rodriguez-Cardenas, Y., Arriola-Guillen, L., Dioses-Tume, Z., Ruiz-Mora, G., \& Aliaga-Del Castillo, A. (2017). Influence of the components Bjork-Jarabak cephalometric analysis on the facial profile. IJO, 28(4), 35-38.

[21] Sakar, O., Çalisir, F., Öztas, E., \& Marsan, G. (2011). Evaluation of the effects of temporomandibular joint disk displacement and its progression on dentocraniofacial morphology in symptomatic patients using lateral cephalometric analysis. CRANIO®, 29(3), 211-218. https://doi.org/10.1179/ crn.2011.030

[22] Sassouni, V. (1955). A roentgenographic cephalometric analysis 
of cephalo-facio-dental relationships. American Journal of Orthodontics and Dentofacial Orthopedics, 41(10), 735-764. doi: 10.1016/0002-9416(55)90171-8

[23] Soboñ, J. S., Cherkasova, O. V., Gunas, V. I., Babych, L. V., \& Kotsyura, O. O. (2020). Correlations of linear sizes of molars with cephalometric indicators of practically healthy men of the southern region of Ukraine. Biomedical and Biosocial Anthropology, 38, 36-46. https://doi.org/10.31393/bba38-202006

[24] Takeda, S., Mine, Y., Yoshimi, Y., Ito, S., Tanimoto, K., \& Murayama, T. (2021). Landmark annotation and mandibular lateral deviation analysis of posteroanterior cephalograms using a convolutional neural network. Journal of Dental Sciences, 16(3), 957-963. https://doi.org/10.1016/ j.jds.2020.10.012

[25] Tehranchi, A., Motamedian, S. R., Saedi, S., Kabiri, S., \& Shidfar, S. (2017). Correlation between frontal sinus dimensions and cephalometric indices: A cross-sectional study. European journal of dentistry, 11(01), 64-70. https://doi.org/10.4103/ 1305-7456.202630

[26] Trainito, S., Favero, L., Martini, G., Pedersen, T. K., Favero, V.,
Herlin, T., \& Zulian, F. (2012). Odontostomatologic involvement in juvenile localised scleroderma of the face. Journal of paediatrics and child health, 48(7), 572-576. https://doi.org/ 10.1111/j.1440-1754.2012.02435.x

[27] Urzua, B., Ortega-Pinto, A., Farias, D. A., Franco, E., MoralesBozo, I., Moncada, G., ... \& Cifuentes, V. (2012). A multidisciplinary approach for the diagnosis of hypocalcified amelogenesis imperfecta in two Chilean families. Acta Odontologica Scandinavica, 70(1), 7-14. https://doi.org/ 10.3109/00016357.2011.574973

[28] Vakhovskyi, V. V., Shinkaruk-Dykovytska, M. M., Pogorila, A. V., Likhitskyi, O. O., \& Gunas, I. V. (2020). Correlations of characteristics of basal cranial structures determined by Bjork and Jarabak methods with teleradiographic parameters of the upper and lower jaws and tooth location in boys and girls with orthognathic occlusion. Biomedical and Biosocial Anthropology, 41, 52-59. doi: 10.31393/bba41-2020-09

[29] Zaki, M. E., Soliman, M. A. T., \& El-Bassyouni, H. T. (2012). A cephalometric study of skulls from the Bahriyah oasis. Journal of forensic dental sciences, 4(2), 88-92. https://doi.org/ $10.4103 / 0975-1475.109895$

\section{КОРЕЛЯЦІЇ ТЕЛЕРЕНТГЕНОГРАФІЧНИХ ПАРАМЕТРІВ РОЗТАШУВАННЯ ЗУБІВ, ВИЗНАЧЕНИХ ЗА МЕТОДАМИ ВЈОRК, JARABAK I SASSOUNI 3 ПAРAMETPAMИ ВЕРХНЬОÏ Й НИЖНЬОÏ ЩЕЛЕП У ЮНАКІВ І ДІВЧАТ ІЗ ОРТОГНАТИЧНИМ ПРИКУСОМ}

\section{Ваховський В. В.}

Анотація. Визначення особливостей тих чи інших показників всередині певної популяції, взаємозв'язку між певними анатомічними структурами та параметрами тіла людини є одним з ключових завдань клінічної антропології. Виявлення природи, сили та напряму взаємозалежностей таких показників є ключовим елементом не тільки для розуміння природи людини, але і вирішення клінічних, зокрема і стоматологічних задач сьогодення. Мета дослідження - встановити в українських юнаків і дівчат із ортогнатичним прикусом особливості кореляцій телерентгенографрічних параметрів розташування зубів, визначених за методами Bjork, Jarabak i Sassouni, з параметрами верхньої й нижньої щелеп та розташуванням зубів. Телерентгенографрію в режимі цефралометричного дослідження проведено 49 юнакам і 76 дівчатам, що мали ортогнатичний прикус. Цефалометричний аналіз виконано за допомогою програмного забезпечення OnyxCeph ${ }^{3}$ тм, версії 3DPro, компанії Image Instruments $\mathrm{GmbH}$, Німеччина (ліцензія на програмне забезпечення № URSQ-1799). Оцінку кореляцій проведено в ліцензійному пакеті "Statistica 6.0" з використанням непараметричного методу Спірмена. В юнаків і дівчат встановлені особливості множинних кореляцій телерентгенографрічних параметрів верхньої й нижньої щелеп із параметрами розташування зубів, визначених за методами CFT-Bjork, Roth-Jarabak i Sassouni. У результаті кількісного аналізу достовірних кореляцій між телерентгенографрічними параметрами верхньої й нижньої щелеп із параметрами розташування зубів встановлено: за методикою CFT-Bjork в юнаків 46,9 \%, з яких, 5,4 \% прямих сильних, 18,5 \% прямих середньої сили і 2,3 \% прямих слабких та 2,3 \% зворотних сильних, 16,2 \% зворотних середньої сили і 2,3 \% зворотних слабких, а у дівчат - 38,5 \%, з яких, 2,3 \% прямих сильних, 15,4 \% прямих середньої сили і 6,2 \% прямих слабких та 0,8 \% зворотних сильних, 7,7 \% зворотних середньої сили i 6,2 \% зворотних слабких; за методикою Roth-Jarabak в юнаків 36,2 \%, з яких, 6,6 \% прямих сильних, 11,8 \% прямих середньої сили і 2,6 \% прямих слабких та 2,6 \% зворотних сильних, 11,8 \% зворотних середньої сили і 0,7 \% зворотних слабких, а у дівчат - 44,7 \%, з яких, 3,9 \% прямих сильних, 15,1 \% прямих середньої сили і 7,2 \% прямих слабких та 0,7 \% зворотних сильних, 8,6 \% зворотних середньої сили і 9,2 \% зворотних слабких; за методикою Sassouni в юнаків 42,8 \%, усі прямі середньої сили, а у дівчат - також 42,8 \%, з яких, 35,7 \% прямих середньої сили і 7,1 \% прямих слабких. Прояви статевого диморфрізму отриманих кореляцій встановлені лише між показниками, визначеними за методами CFT-Bjork i Roth-Jarabak. Ключові слова: телерентгенографія, цефралометрія за методиками Jarabak, Bjork i Sassouni, кореляції, юнаки та дівчата з ортогнатичним прикусом. 